\title{
CHOVÁNÍ SENDVIČOVÝCH KOMPOZITNÍCH PANELŮ PŘI NAMÁHÁNÍ OHYBEM
}

\section{BEHAVIOUR OF SANDWICH COMPOSITE PANELS UNDER BENDING STRESS}

\author{
Pavlína Zlámalová*,1
}

\author{
${ }^{*}$ zlamalova.pce.vutbr.cz \\ ${ }^{1}$ Vysoké učení technické v Brně, Fakulta stavební, Veveři 331/95, 60200 Brno
}

\begin{abstract}
Abstrakt
Př́íspěvek prezentuje ověření chování kompozitních nosníků na bázi FRP materiálů, které byly provedeny v různých konfiguracích, tak aby umožnily popsat vliv povrchové vrstvy laminátu a vliv spoje nosníku v místě stojiny a pásnice na výsledné chování konstrukčního prvku. Jeho využití spadá zejména do oblasti agresivního prostředí (např. ČOV), kde tyto materiály, oproti železobetonu, vykazují vyšší odolnost a stálost. Optimálním využitím kompozitních materiálů, vzniká kompozitní nosník s relativně vysokou tuhostí, únosností a vysokou odolností vůči agresivnímu prostředí při velmi nízké vlastní hmotnosti.

Výsledkem provedených experimentů je pak zejména popis chování kompozitního nosníku, vliv povrchové vrstvy laminátu a stanovení fyzikálně-mechanických parametrů sendvičové konstrukce.
\end{abstract}

\section{Klíčová slova}

Kompozitní materiál, sendvičová konstrukce, pultrudovaný kompozitní profil

\begin{abstract}
This paper presents verification of the behaviour of FRP-based composite beams under four-point bending test, which. were made in different configurations to describe the effect of the laminate surface layer and the effect of the joint between the beam at the web and the flange on the resulting behaviour of the structural element. Its application is mainly in the field of aggressive environments (e.g. wastewater treatment plants), where these materials show higher durability and stability compared to reinforced concrete. The optimum use of composite materials results in a composite beam with relatively high stiffness, load-bearing capacity and high resistance to aggressive environments at very low self-weight.

As a result of the experiments, the behaviour of the composite beam, the influence of the laminate surface layer and the determination of the physical-mechanical parameters of the sandwich structure are described.
\end{abstract}

\section{Key words}

Composite material, sandwich construction, pultruded composite profile

\section{1 ÚVOD}

Motivací pro výzkum FRP kompozitního nosníku je zvýšení únosnosti, tuhosti a maximální délky v současné době běžně dostupných nosníků z pultrudovaných profilů. Maximální délky nosníků z pultrudovaných profilů se pohybují okolo 7-8 m, přičemž jejich použití limituje zejména nižší tuhost. Konstrukce FRP nosníku je navržena s cílem maximalizovat moment setrvačnosti při využití stávajících výrobků a vhodným technologickým postupem umožnit výrobu nosníkůs delším rozpětím (okolo $12 \mathrm{~m}$ ). Tyto požadavky definují provedení FRP kompozitního nosníku, který je tvořen složeným prưřezem, kdy pásnice jsou provedeny z pultrudovaných GFRP profillů TT průřezu a stojina je z litého kompozitního roštu ze skelných vláken (výrobní ozn. PrefaGrid). Díky variabilitě kompozitního roštu (tloušt'kou stěny, velikostí ok, výškou roštu) lze s výhodou měnit výšku nosníku a ovlivňovat tak jeho ohybovou tuhost. Provedení nosníku je patrné z Obr. 1. 


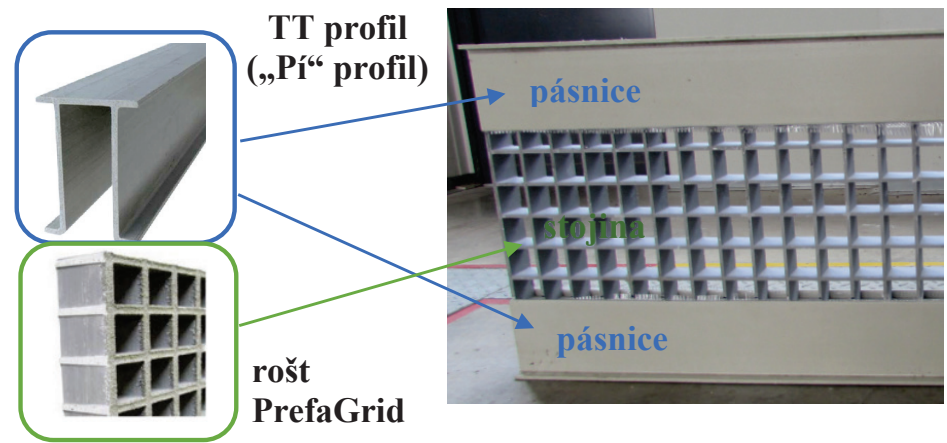

a) jednotlivé dílce nosníku

b) nově navržený nosník

Obr. 1 Zobrazení jednotlivých materiálů navrženého nosníku.

Základní mechanické vlastnosti dílčích částí tvořících dílec (rošt PrefaGrid výšky $50 \mathrm{~mm}$ s velikostí oka 50x50 mm) byly uváženy dle uvedeného v Tab. 1 .

Tab. 1 Základní mechanické vlastnosti dílčích částí nosníku.

\begin{tabular}{cccccc}
\hline Materiál & $\begin{array}{c}\text { Pevnost v } \\
\text { tlaku } \\
{[\mathrm{MPa}]}\end{array}$ & $\begin{array}{c}\text { Modul pružnosti } \\
\text { v tlaku } \\
{[\text { GPa] }}\end{array}$ & $\begin{array}{c}\text { Pevnost v } \\
\text { tahu } \\
{[\mathrm{MPa}]}\end{array}$ & $\begin{array}{c}\text { Modul } \\
\text { pružnosti v } \\
\text { tahu } \\
{[\mathrm{GPa}]}\end{array}$ & $\begin{array}{c}\text { Ohybová } \\
\text { pevnost } \\
{[\mathrm{MPa}]}\end{array}$ \\
\hline PREFAGRID 44x44/50 & 135 & 16 & 255 & 19 & 260 \\
TT PROFIL 140x100/5 & $\geq 240$ & $\geq 19$ & $\geq 240$ & $\geq 14$ & $\geq 270$ \\
\hline
\end{tabular}

\section{POPIS EXPERIMENTÁLNĚ ZKOUŠENÝCH NOSNÍKŮ V OHYBU}

Prvotní experimentální práce byly zaměřeny na základní popis chování FRP kompozitního nosníku v délce rovné maximální délce roštu, kterou je možno za běžných podmínek vyrábět - tj. 3,2 m. Cílem zatěžovacích zkoušek bylo ověřit předpoklady pro návrh nosníku, tzn. ověřit funkčnost spolupůsobení dílčích částí nosníku, popsat vliv povrchové vrstvy laminátu, popsat způsob porušení a okamžik selhání lepeného spoje pásnice/stojina [1].

Pro ověření stykování a celkového chování nosníku bylo navrženo a vyrobeno 6 vzorků, které se vzájemně liší provedením stykování stojiny a zároveň materiálovým řešením kompozitního nosníku. Zkušební vzorky dílců byly vyrobeny ve dvou typech, které se lišili provedením bez povrchové vrstvy laminátu a s ní. První typ představuje základní segment z kompozitního roštu tvořícího stojinu a TT profilu tvořícího horní a dolní pásnici (vzorky s označením „1“ viz Obr. 2a). Druhý typ nosníku byl doplněn o povrchovou vrstvu laminátu, která byla nalepena na povrch stojiny a překrývala i části horní a dolní pásnice (vzorky s označením „2“ viz Obr. 2b).

Pro každý typ $\left(, 1^{\prime \prime} a, 2^{2}\right)$ kompozitního dílce pak byly použity tři různé varianty podélného řešení stojiny. V první variantě je vzorek spojitý po celé délce (vzorky s označením „A“). V druhé variantě je stojina tvořena ze dvou částí, které jsou propojeny zazubením v místě maximálního ohybového namáhání (vzorky s označením „B“).

U třetí varianty nosníku je stojina tvořena ze tří částí, které jsou spojeny zazubením v krajních čtvrtinách rozpětí, tzn. v místě s maximálním smykovým namáháním (vzorky s označením „C“).

Pro experimentální ověření chování nosníkủ byla zvolena zkouška čtyřbodovým ohybem. Podepření nosníku je realizováno prostřednictvím roznášecích ocelových desek uložených na kluzných podporách. V místě krajních podpor byl kompozitní nosník vsazen do ocelového rámu, který zabraňoval vybočení v příčném směru, ovšem nebránil volnému pootáčení v místě podpory. Zatížení bylo vnášeno do horní pásnice $0,5 \mathrm{~m}$ od osy nosníku na každou stranu (viz Obr. 3a) konstantní rychlostí $0,5 \mathrm{kN} / \mathrm{s}$ až do porušení. 


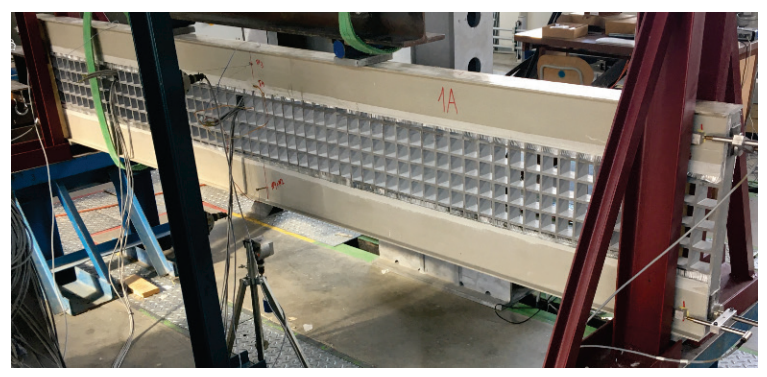

a) nosník bez vnějších vrstev laminátu

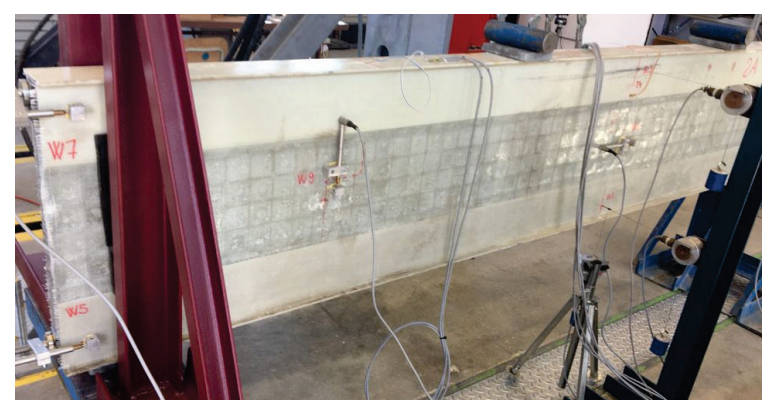

b) nosník s vnějšími vrstvami laminátu

Obr. 2 Konfigurace zkoušky - skutečné provedení.

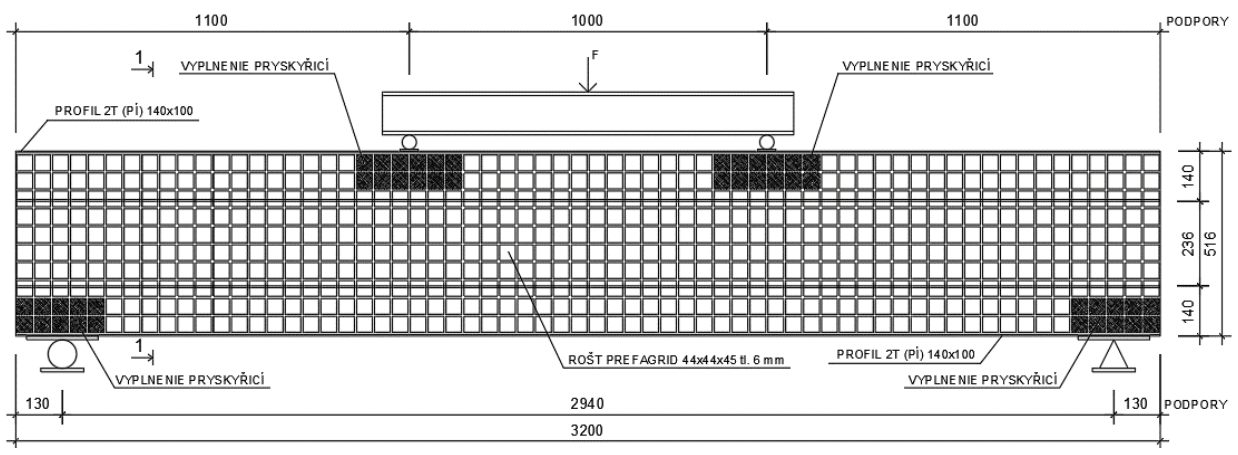

a) zobrazení kompozitního FRP segmentu 


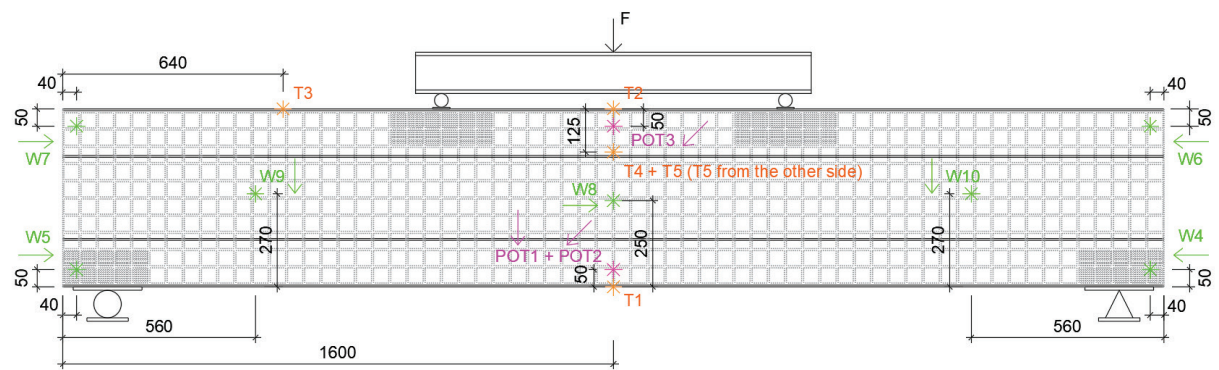

b) zobrazení osazení snímačů na segmentu

Obr. 3 Schematické znázornění kompozitního FRP segmentu.

Zkušební vzorky FRP kompozitních nosníků byly osazeny řadou snímačů (viz Obr. 3b) pro dostatečně výstižný popis jejich chování během zatěžovací zkoušky. Při zkoušce byly kromě velikosti vnášení síly sledovány svislá deformace uprostřed rozpětí (průhyb), vodorovný posun mezi pásnicemi a stojinou v místě podpor (popis chování lepeného spoje a okamžiku jeho selhání), posuny v místě spojení stojiny (popis lepeného spoje roštu), vodorovný posun uprostřed rozpětí (příčná deformace popisující případné boulení nosníku), přetvoření horní a dolní pásnice uprostřed rozpětí.

\section{VYHODNOCENÍ EXPERIMENTU゚}

Z výsledků provedených experimentů je v první řadě zřejmý výrazný vliv nalepené vrstvy tkaniny na povrchu prvku. Tato ovlivňuje celkové chování FRP kompozitního nosníku podstatným zvýšením tuhosti i únosnosti a jeví se jako vhodné řešení do exponovaných částí nosníku. Při porovnání prvního a druhého typu nosníku, tedy bez a s povrchovou vrstvou laminátu je dosahováno přibližně trojnásobné únosnosti, resp. přibližně desetinásobné zvýšení tuhosti (viz Obr. 4).

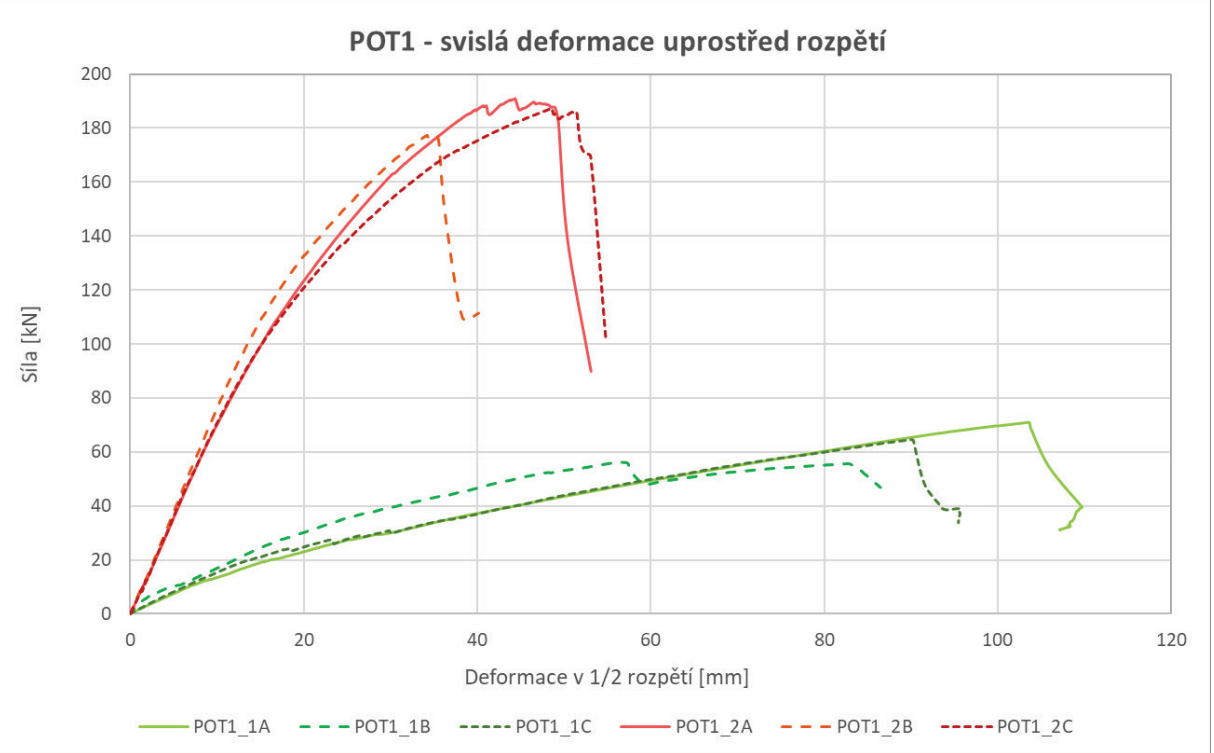

Obr. 4 Zatěžovací diagram kompozitních FRP nosníků. 
Z dosažených výsledků je zároveň zřejmé, že oblast porušení se nenacházela uprostřed nosníku, ale mezi podporou a břemenem (viz Obr. 6). Kritickým místem FRP kompozitního nosníku je pásnice, resp. spoj pásnice a stojiny v místě tlakového namáhání. Selhání kompozitního TT profilu, který tvoří horní pásnici nosníku, nastalo roztržením na styku vodorovné a svislé části profilu (viz Obr. 6a). V př́ípadě druhého typu nosníku s povrchovou vrstvou laminátu došlo k selhání obdobným způsobem, tj. v porušením horní pásnice při současném odtržení laminátu tkaniny od stojiny.

V případě tři variant nosníků, tj. bez spojení stojiny a se spojením stojiny uprostřed, resp. v krajních čtvrtinách rozpětí nosníku, lze pozorovat postupné snížení únosnosti vzorků. Nejvyšší únosnosti dosáhl kontinuální vzorek bez spoje (varianta A), lehce nižší únosnost vykazoval vzorek se spojem v krajních čtvrtinách (varianta C) a nejnižší únosnost vykázal vzorek se spojen stojiny uprostřed (varianta B). Snížení únosnosti se pohybuje do cca $10 \%$. Obdobných výsledků je dosaženo i v př́padě porovnání průhybů. U varianty $\mathrm{B}$ je patrný odklon od kontinuálního nosníku při dosažení cca 2/3 maximální únosnosti. Přičemž nárůst průhybu se pohybuje do 20 \%. U var. C došlo dokonce ke snížení průhybu, což lze přičíst zvýšení tuhosti vlivem výplně v místě lepeného spoje stojiny.

Z dalších měřených veličin je pak důležitý zejména vodorovný posun mezi stojinou a spodní pásnicí (Obr. 5), který byl měřen z čela na obou koních nosníků. Ze získaných dat je zřejmé, že při dosažení přibližně 15-30 \% hladiny zatížení (cca 10-20 kN) v případě nosníků bez laminátu, respektive při dosažení hladiny zatížení přibližně 40-50 \% (cca 70-90 kN) pro variantu s povrchovou úpravou laminátem, začínají deformace narůstat. Tento jev se projeví i v mírném snížení tuhosti celého kompozitního nosníku a zrychlení př́růstku svislých deformací a lze jej přičítat pokluzu spoje pásnice/stojiny a postupné redistribuci napětí (Obr. 4).

W4 a W5 - posun mezi spodní pásnicí a stojinou

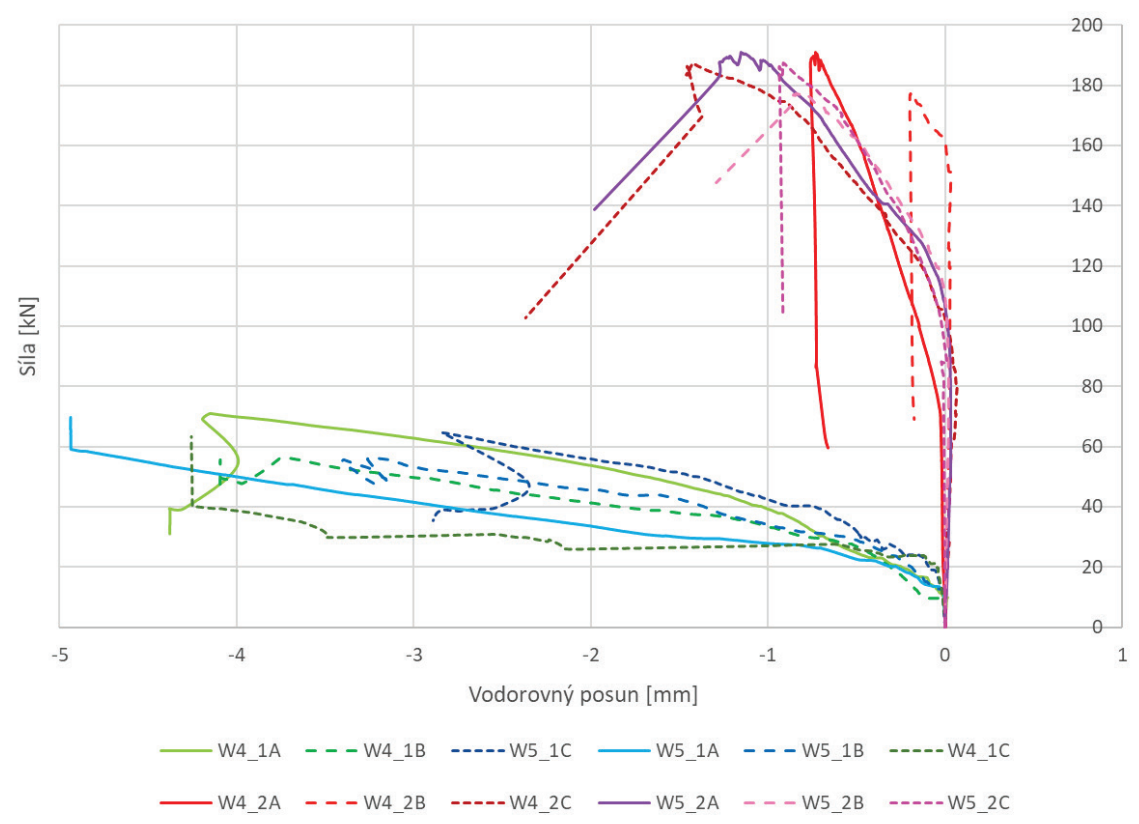

Obr. 5 Vodorovná deformace mezi spodní a horní pásnicí. 


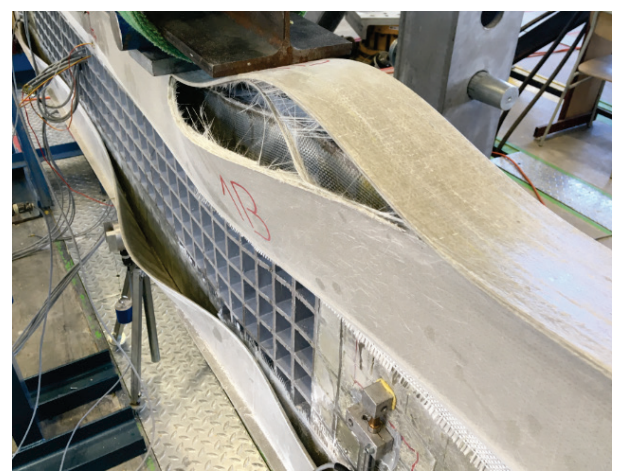

a) vzorek bez vnější vrstvy laminátu

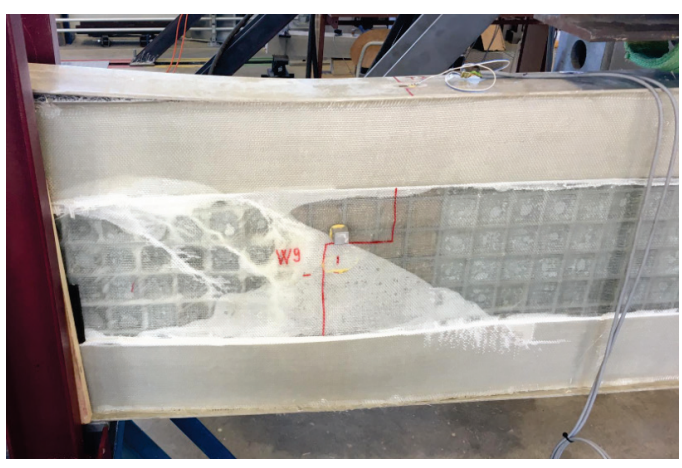

b) vzorek s vnější vrstvou laminátu

Obr. 6 Detail porušení kompozitních nosníků.

\section{ZÁVĚR}

Prezentované výsledky potvrdily funkčnost vyvíjeného kompozitního nosníku, který se do okamžiku pokluzu spoje pásnice/stojina chová lineárně-pružně. Poté dochází k postupnému snížení tuhosti při zvyšující se úrovni zatížení. Díky tomu lze tak snadno přizpůsobit návrh požadavkům rozponu a zatížení. Celkové chování značně ovlivňuje aplikace povrchové vrstvy laminátu FRP tkaniny, která násobně zvyšuje únosnost i tuhost nosníku. Její použití je tak vhodné do exponovaných míst nosníku, napřr. pro budoucí místa spojení nosníku pro zajištění délky přesahující $8 \mathrm{~m}$. Vliv spojení stojiny snižuje únosnost a tuhost prvku, ale vhodnou úpravou spoje vyplněním epoxidem a překrytím vrstvou laminátu lze tento negativní efekt do značné míry eliminovat.

S ohledem na předpokládaný aplikační oblast počáteční zkoušky prokázaly funkčnost řešení. Do budoucna je plánováno ověření spojů nosníků pro vytvoření požadované délky $12 \mathrm{~m}$ a porovnání s železobetonovou variantou.

\section{Poděkování}

Výstupy prezentované $\mathrm{v}$ textu byly získány při řešení projektů FV40278 - Odolné sendvičové nosné prvky z progresivních kompozitních FRP materiálů, FAST-J-21-749 - Mechanické vlastnosti sendvičových kompozitních konstrukcí a FAST-S-21-7503 - Využití nepřímých FRP výztuží při návrhu vybraného detailu bodově podepřené stropní konstrukce.

\section{Použité zdroje}

[1] ČSN EN ISO 17129 Vlákny vyztužené plastové kompozity - Stanovení ohybových vlastností; 1999 